\title{
Leopold Auenbrugger: Camphor-Induced Epilepsy - Remedy for Manic Psychosis
}

\author{
J.M.S. Pearce \\ Emeritus Consultant Neurologist, Department of Neurology, Hull Royal Infirmary and Hull York Medical School, Hull, UK
}

\section{Key Words}

Auenbrugger $\cdot$ Camphor $\cdot$ Epilepsy $\cdot$ Psychosis $\cdot$ Diagnostic percussion

\begin{abstract}
Leopold Auenbrugger invented the art of diagnostic percussion. This paper recalls his use of camphor to induce epileptic fits, which were considered a remedy for psychosis. The initiation of the art of percussion by Auenbrugger is outlined, with a brief biographical sketch.
\end{abstract}

Copyright $\odot 2007$ S. Karger AG, Basel

There are few medical names which commemorate discoveries that have transformed medical practice. Undoubtedly, Leopold Auenbrugger's (fig. 1) is one. He invented the art of diagnostic percussion published as Inventum novum ex percussione thoracis humani ut signo abstrusos interni pectoris morbos detegendi [1-3]. Another contribution was to use camphor in the treatment of psychosis by inducing epileptic seizures.

\section{Camphor-Induced Epilepsy}

Spontaneous fits of epilepsy were, in the mid-eighteenth century, thought to be antagonistic to psychosis (now called 'alternative psychosis'), so artificially induced fits might similarly protect from mental illness. In the first edition of his book, Experimentum nascens de remedio specifico sub signo specifico in mania virorum (fig. 2)
[4], Auenbrugger described his treatment of psychotic patients suffering from mania, with camphor, which has epileptogenic properties [5]. He was not the first to attempt treatment of psychoses by such means. In the 16th century in Switzerland, Paracelsus had induced seizures with camphor to treat psychosis [6]. Dr. Robert Whytt described similar treatment in 1751 in his book Observations on the Nature, Cause, and Cure of Those Disorders Which Are Commonly Called Nervous, Hypochondriac or Histeric [7]. Dr. William Oliver, in 1785, reported in The London Medical Gazette the histories of 2 patients to whom he had given oral camphor to induce fits.

Camphor in certain types of insanity was considered comparable to opium in pain and quinine in malarial fevers. Auenbrugger gave increasing doses to his patients until severe convulsions were induced. Because of this action, camphor was reintroduced in the 1930s to produce convulsions in schizophrenics predicated on the supposed biological antagonism between schizophrenia and epilepsy, which in turn was based on the false premise that they never occurred together. Camphor $\left(\mathrm{C}_{10} \mathrm{H}_{16} \mathrm{O}\right)$ is extracted from the tree Cinnamonum camphora ${ }^{1}$ or is synthesized from the hydrocarbon pinene, a turpentine derivative. It may also be synthetically derived. Some products such as lotions and moth repellents still contain camphor. In 1980, the Food and Drug Administration set a limit of $11 \%$ allowable camphor in consumer products and banned products labelled as camphorated oil, cam-

\footnotetext{
${ }^{1}$ A magnificent dense broadleaved evergreen that may grow $50-150 \mathrm{ft}$ $(15.2-45.7 \mathrm{~m})$ tall, spreading twice that wide, with a trunk up to $15 \mathrm{ft}$ $(4.6 \mathrm{~m})$ in diameter.
}

\section{KARGER}

Fax +41 613061234 E-Mail karger@karger.ch www.karger.com

\section{(C) 2007 S. Karger AG, Basel \\ 0014-3022/08/0592-0105\$24.50/0}

Accessible online at:

www.karger.com/ene
J.M.S. Pearce

304 Beverley Road

Anlaby, East Yorks HU10 7BG (UK) 


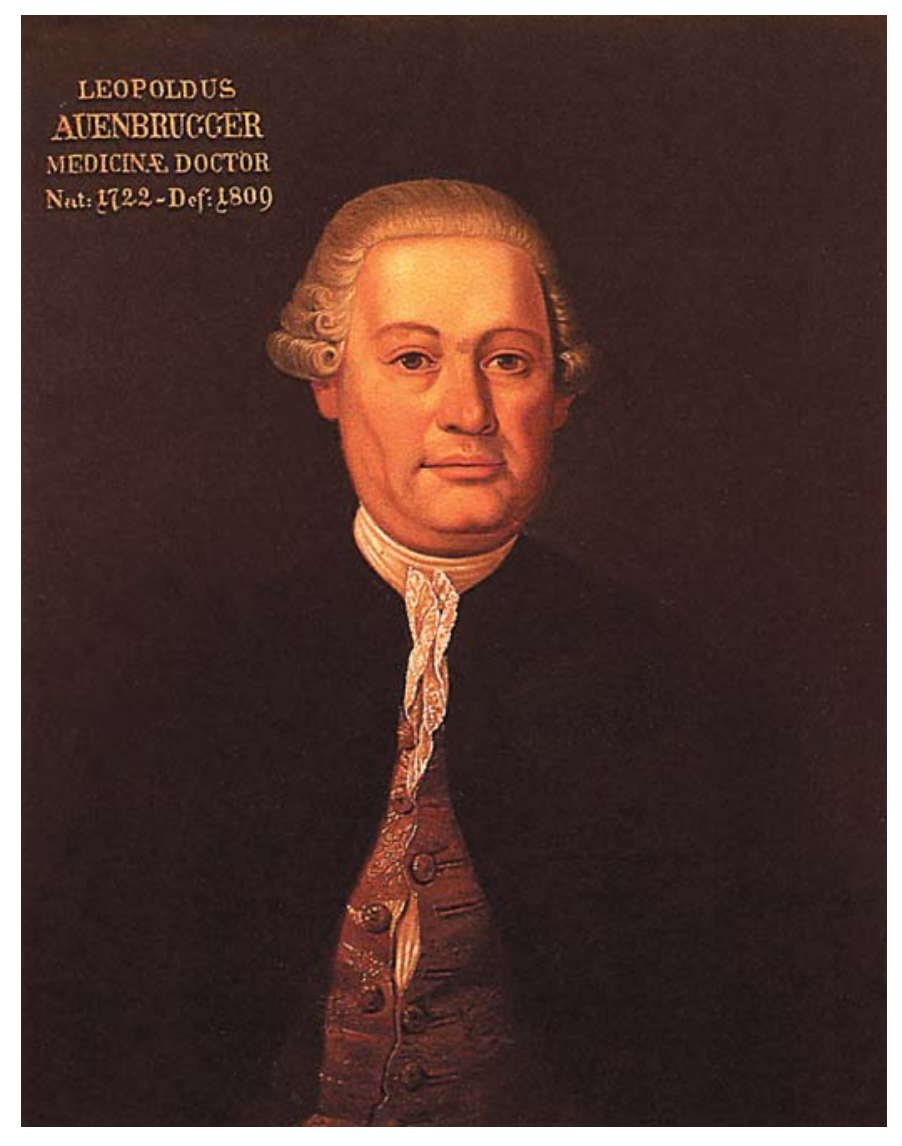

Fig. 1. Josef Leopold Auenbrugger. Courtesy of Royal College of Physicians and Surgeons of Glasgow.

phor oil and camphor liniments. In the 1930s, camphor was replaced by pentylenetetrazole (Metrazol). The subsequent development of the electroconvulsive therapy is well known.

\section{Career}

Auenbrugger was born on November 19, 1722, in Graz, Austria. There as a boy, he learned how to tap wine barrels for his father, an innkeeper, in the cellar to find how full they were; so perhaps that is where the seeds of his ideas of percussion were germinated. He studied medicine at the University of Vienna where he graduated on November 18, 1752.

After graduation, he studied under Gerhard van Swieten (1700-1772), himself a student of the famous Boerhaave in Leiden [8], who had made many neurological contributions. Auenbrugger worked without taking fees from 1751 to 1755 to help impoverished patients and stu-
Fig. 2. Title page.

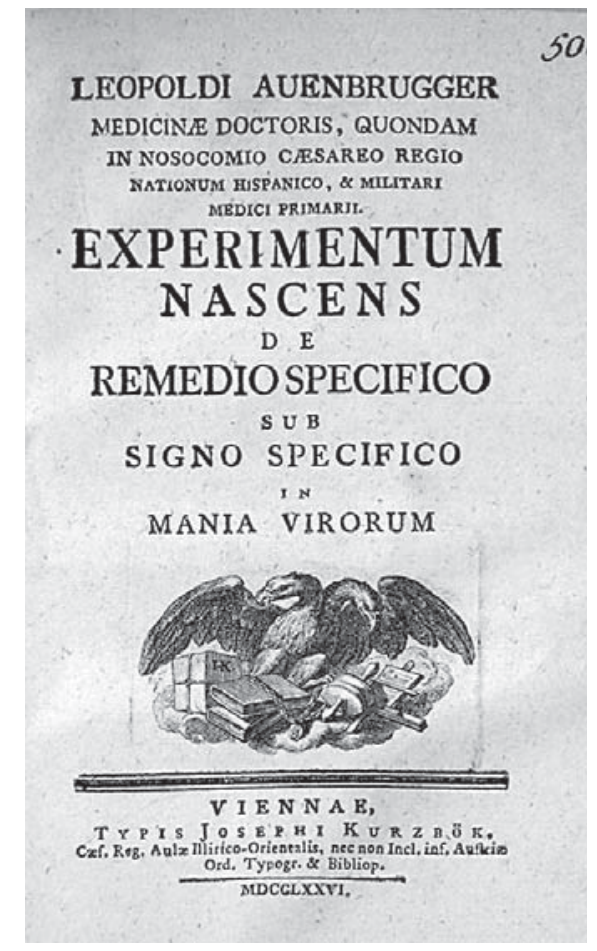

dents alike. It was during that period that he conceived his idea of the possible diagnostic applications of percussion. He spent 10 years at the Spanish Military Hospital of Vienna, developing and testing his newly discovered percussion, aided no doubt by considerable musical abilities; in 1781, he wrote the libretto for Mozart's antagonist, Antonio Salieri's comic opera Der Rauchfangkehrer ('The Chimney Sweep').

He became senior physician in 1758. Aged 61, Emperor Franz Joseph II honoured him with a knighthood in 1783. Auenbrugger then adopted his name - Josef.

\section{Percussion of the Thorax}

Auenbrugger is, however, best remembered [9] for his original work on percussion of the chest [10], which he published 7 years after his discovery. At the Spanish Military Hospital, he had encountered innumerable cases of lung disease especially tuberculosis. At autopsy, he found that many of his patients had pleural effusions, and he wondered if they could be diagnosed in life. Was the thorax like one of his father's wine barrels that would yield sounds to indicate its fluid level? With his fingertips gently striking his patients' chests, he tapped out sounds and detected the fluid level. He called his technique 'percussion'. 
Auenbrugger reassessed and refined the diagnostic method of percussion over more than 7 years after he first discovered its significance in 1754 . He compared his physical signs with post-mortem findings. He also injected fluid into the pleural cavity and showed that it was possible by percussion to tell exactly the limits of the fluid present, and thus to decide where it was best removed. Although Maximilian Stoll (1742-1788), director of the medical clinic at the Spanish Hospital, praised his work, neither the art of percussion nor Auenbrugger's book Inventum novum expercussione thoracis ... ('A new discovery from the percussion of the human thorax that detects internal disease within the chest') [3] achieved general approval. He became only too familiar with rejection:

'I have not been unconscious of the dangers I must encounter; since it has always been the fate of those who have illustrated or improved the arts and sciences by their discoveries, to be beset by envy, malice, hatred, detraction, and calumny.'

Robertson [11] reported a case illustrating the sign of Sir William MacEwen (1848-1924) who applied percussion to the skull where it produced a crack pot sound in patients with hydrocephalus. In the 1920s, László Benedek of the Debrecen Science University, Hungary, extended the method. He found that tumours conduct the percussion waves differently than does healthy brain tissue.

Percussion was later used to detect ascites and abdominal masses. Cardiologists, too, attempted to delineate the heart's borders and size, and differentiate cardiomegaly from pericardial effusion. Auenbrugger said that percussion of the healthy thorax produced a resonant note. Percussion provided an objective physical sign of thoracic disease. He recognized three categories of sounds: a sonus altior ('high-pitched'), a sonus carnis ('dull') and a sonus obscurior ('muffled/indistinct').

His work was noticed and used by René Laënnec (17811826), who discovered auscultation (De l'auscultation médiate, 1819). However, Auenbrugger's book Inventum novum ex percussione thoracis humani ut signo abstrusos interni pectoris morbos detegendi made little general impression until translated nearly 50 years later into French by Corvisart [12].

Later appreciation [13] is exemplified by the following respected text (Heirs of Hippocrates, No. 954):

'This small book is one of the greatest of all medical classics and contains the results of Auenbrugger's experience with a new method of physical diagnosis - thoracic percussion ... one of the milestones in the history of medicine.'

The technique was further developed by Joseph Skoda (1805-1881), Pierre A. Piorry (1794-1879) who devised a pleximeter to refine digital percussion [14], and Laënnec who added the important art of auscultation.

Auenbrugger died aged 87 from pneumonia. It is said that he predicted his own death:

'Shortly before noon of the day of his death, he surveyed his condition and looking at the clock, stated that when 2 pm arrived he would have passed on.'

Auenbrugger Platz, the site of the Medical University of Graz, commemorates his name. In 1780, Artaria published a set of six piano sonatas by Haydn (Hob. XVI: 20, 35-39) dedicated to the piano virtuoso sisters, Maria Katharina and Marianna, who were his daughters.

\section{References}

1 Davies MK, Hollman A: Joseph Leopold Auenbrugger (1722-1809). Heart 1997;78: 102.

$\checkmark 2$ Kukowka A: Leopold Auenbrugger, nobleman of Auenbrugg (1722-1809), inventor of thorax percussion. 250th anniversary. Z Allgemeinmed 1972;48:1502-1510.

3 Auenbrugger L: Inventum novum ex percussione thoracis humani ut signo abstrusos interni pectoris morbos detegendi. Vienna, Trattner, 1761.

4 Auenbrugger L: Experimentum nascens de remedio specifico sub signo specifico in mania virorum. Vienna, Kurzbök, 1776.

5 Lesky E: Auenbrugger's camphor therapy and the convulsive therapy of psychoses: on the occasion of the 150th anniversary of Auenbrugger's death on 18th May 1959. Wien Klin Wochenschr 1959;71:289-293.
6 Dubovsky SL: Electroconvulsive therapy; in Kaplan HI, Sadock BJ (eds): Comprehensive Textbook of Psychiatry, ed 6. Baltimore, Williams and Wilkins, 1995, p 2129.

7 Whytt R: Observations on the nature, causes and cure of those disorders which are commonly called nervous, hypochondriac, or hysteric to which are prefixed some remarks on the sympathy of the nerves; in Becket $\mathrm{T}$, du Hondt P (eds): The Works of Thomas Whytt, ed 3. London, Becket and du Hondt, 1767

8 Pearce JMS: Van Swieten's concept of cerebral embolic stroke. J Neurol Neurosurg Psychiatry 2002;73:153.

-9 Sakula A: Auenbrugger: opus and opera. J R Coll Physicians Lond 1978;12:180-188.

10 Jarcho S: Auenbrugger, Laennec, and John Keats. Some notes on the early history of per- cussion and auscultation. Med Hist 1961;5: 167-172.

11 Macmillan M: Localization and William MacEwen's early brain surgery. 2 . The cases. J Histo Neurosci 2005;14:24-56.

12 Corvisart JN: Nouvelles méthodes pour reconnaître les maladies internes de la poitrine par la percussion de cette cavité, par Auenbrugger. Paris, Migneret, 1808.

13 Bishop PJ: A bibliography of Auenbrugger's 'Inventum novum' (1761). Tubercle 1961;42: 75-90; Willius \& Keys, pp 190-213.

14 Piorry PA: Des maladies de la plèvre; in Piorry PA (ed): De la percussion médiate et des signes obtenus à l'aide de ce nouveau moyen d'exploration dans les maladies des organes thoraciques et abdominaux. Paris, Chaudé et Baillière, 1828, pp 62-95. 